\title{
PENGGUNAAN MODEL PEMBELAJARAN MULTILEVEL GROUP UNTUK MENINGKATKAN AKTIVITAS DAN HASIL BELAJAR MATEMATIKA MATERI KPK DAN FPB DI KELAS VI SDN KETAWANG KARAY I KEC. GANDING KAB. SUMENEP SEMESTER 1 TAHUN PELAJARAN 2018/2019
}

\author{
Rahwini \\ SDN Ketawang Karay I \\ rahwinispd@gmail.com
}

\begin{abstract}
Abstrak
Penelitian ini bertujuan untuk meningkatkan aktivitas dan hasil belajar matematika materi KPK Dan FPB pada peserta didik kelas VI SDN Ketawang Karay I Kecamatan Ganding Kabupaten Sumenep Semester 1 Tahun Pelajaran 2018/2019 dengan menggunakan model pembelajaran Multilevel Group. Jenis penelitian ini adalah penelitian tindakan kelas berkolaborasi dengan teman sejawat. Hasil penelitian menunjukkan bahwa penggunaan model pembelajaran Multilevel Group dapat meningkatkan keaktifan peserta didik dalam pembelajaran Matematika materi KPK Dan FPB. Pada aspek percaya diri, pada siklus I dengan kategori baik, aspek percaya diri $54 \%$, aspek keaktifan $69 \%$, aspek motivasi belajar $46 \%$, dan aspek kerjasama $62 \%$. Pada siklus II dengan kategori baik, meningkat yaitu aspek percaya diri menjadi $92 \%$, aspek keaktifan menjadi $85 \%$, aspek motivasi belajar menjadi $85 \%$, dan aspek kerjasama menjadi $77 \%$. Hasil penelitian juga menunjukkan bahwa penggunaan model pembelajaran Multilevel Group dapat meningkatkan hasil belajar peserta didik dalam pembelajaran Matematika materi KPK Dan FPB. Pada tahap prasiklus nilai rata-rata kelas 55 dengan ketuntasan klasikal $23 \%$, pada siklus I nilai rata- rata kelas menjadi 71 dengan ketuntasan klasikal $62 \%$, dan pada siklus II nilai rata- rata meningkat menjadi 84 dengan ketuntasan klasikal 92\%.
\end{abstract}

Kata Kunci: Hasil Belajar, KPK dan FPB, Matematika, Multilevel Group

\begin{abstract}
This study aims to improve the activities and mathematics learning outcomes of the KPK and FPB material in class VI students of Ketawang Karay I Elementary School in Ganding Subdistrict, Sumenep Regency, 1st Semester Academic Year 2018/2019 using the Multilevel Group learning model. This type of research is classroom action research in collaboration with colleagues. The results of the study showed that the use of the Multilevel Group learning model could increase the activeness of students in the Mathematics learning material of the $K P K$ and FPB. In the aspect of confidence, in the first cycle with good categories, 54\% confidence aspects, 69\% activeness aspects, $46 \%$ learning motivation aspects, and $62 \%$ collaboration aspects. In the second cycle with a good category, it increased the self-confidence aspect to $92 \%$, the activeness aspect to $85 \%$, the learning motivation aspect to $85 \%$, and the collaboration aspect to $77 \%$. The results also show that the use of the Multilevel Group learning model can improve student learning outcomes in the Mathematics learning material of the $K P K$ and FPB. In the pre-cycle stage the average grade of 55 with classical completeness was $23 \%$, in the first cycle the average grade was 71 with $62 \%$ classical completeness, and in the second cycle the average value increased to 84 with 92\% classical completeness.
\end{abstract}

Keywords: Learning Outcomes, KPK and FPB, Mathematics, Multilevel Group 


\section{Pendahuluan}

Peneliti sebagai guru kelas, telah berusaha maksimal untuk meningkatkan mutu dan hasil pembelajaran Matematika, khususnya dalam materi KPK dan FPB di kelas VI. Pembelajaran dilaksanakan sesuai dengan Rencana Pelaksanaan Pembelajaran yang telah disusun. Namun, hasil yang dicapai belum sesuai dengan harapan karena banyak yang belum mampu mencapai KKM yang ditentukan yaitu nilai 70. Dari 13 peserta didik di kelas VI, hanya 3 peserta didik yang mencapai nilai KKM, sedangkan 10 peserta didik lainnya belum mencapai KKM. Rata-rata kelas pun masih rendah yaitu 55 .

Hasil observasi awal yang digunakan oleh peneliti menunjukkan model pembelajaran konvensional yakni suatu model pembelajaran yang banyak didominasi oleh guru, sementara peserta didik duduk secara pasif menerima informasi pengetahuan dan ketrampilan. Hal ini diduga merupakan salah satu penyebab terhambatnya kreatifitas dan terhambatnya kemandirian peserta didik sehingga menurunkan prestasi belajar matematika peserta didik.

Melihat fenomena tersebut maka perlu diterapkan suatu sistem pembelajaran yang melibatkan peran peserta didik secara aktif dalam kegiatan pembelajaran, guna meningkatkan prestasi belajar disetiap jenjang pendidikan. Salah satu model pembelajaran yang diharapkan mampu melibatkan peran peserta didik secara aktif dalam pembelajaran Matematika adalah model pembelajaran kooperatif. Model pembelajaran kooperatif sangat cocok diterapkan pada pembelajaran matematika, karena pada pembelajaran matematika tidak cukup hanya mengetahui dan menghafal konsep-konsep matematika, tetapi juga dibutuhkan suatu pemahaman serta kemampuan menyelesaikan persoalan matematika dengan baik dan benar. Melalui model pembelajaran ini peserta didik dapat menemukan pemikiran, saling bertukar pendapat, saling bekerjasama jika ada teman dalam satu kelompok yang mengalami kesulitan. Hal ini dapat meningkatkan proses belajar peserta didik untuk mengkaji dan menguasai materi pembelajaran matematika sehingga nantinya akan meningkatkan prestasi belajar matematika peserta didik.

Hasil belajar merupakan kulminasi dari suatu proses yang telah dilakukan dalam belajar. Kulminasi akan selalu diiringi dengan kegiatan tindak lanjut. Hasil belajar harus menunjukkan suatu perubahan tingkah laku atau perolehan perilaku yang baru dari peserta didik yang bersifat menetap, fungsional, positif, dan disadari. Bentuk perubahan tingkah laku harus menyeluruh secara komprehensif sehingga menunjukkan perubahan tingkah laku seperti contoh diatas.

Menurut Benyamin Bloom (1959) yang dapat menunjukkan gambaran hasil belajar, mencakup aspek kognitif, afektif, dan psikomotorik. Sedangkan menurut Romizoswki (1982) menyebutkan dalam skema kemampuan yang dapat menunjukkan hasil belajar yaitu: 1) keterampilan kognitif yang berkaitan dengan kemampuan membuat keputusan memecahkan masalah dan berpikir logis; 2) keterampilan psikomotor berkaitan dengan kemampuan tindakan fisik dan kegiatan perseptual; 3) keterampilan reaktif berkaitan dengan sikap, kebijaksanaan, perasaan, dan self control; 4) keterampilan interaktif berkaitan dengan kemampuan sosial dan kepemimpinan (Sudjana, 2005: 34).

Menurut Gagne (1979) dalam Ibrahim (1993:23) menyebutkan ada lima tipe hasil belajar yang dapat dicapai oleh peserta didik 1) motor skills; 2) verbal information; 3) intelectual skills; 4) attitudes; 5) cognitive strategies. 
Berdasarkan uraian diatas dapat disimpulkan bahwa hasil belajar merupakan perubahan perilaku secara menyeluruh bukan hanya pada satu aspek saja tetapi terpadu secara utuh. Perwujudan hasil belajar akan selalu berkaitan dengan kegiatan evaluasi pembelajaran sehingga diperlukan adanya teknik dan prosedur evaluasi belajar yang dapat menilai secara efektif proses dan hasil belajar.

Sehingga salah satu cara dalam meningkatkan hasil belajar Matematika adalah dengan cara menerapkan model pembelajaran multiple group. Model pembelajaran merupakan cara melakukan atau menyajikan, menguraikan, memberikan contoh, dan memberi latihan isi pelajaran kepada peserta didik untuk mencapai tujuan tertentu (Zaini, 2005: 13).

Dalam pembelajaran guru harus menggunakan metode atau model pembelajaran yang bervariasi sesuai dengan materi yang akan disampaikan. Fungsi metode atau model pembelajaran adalah sebagai alat untuk mencapai tujuan pembelajaran. Penggunaan model pembelajaran yang tepat sangat membantu guru dalam meningkatkan minat belajar peserta didik di sekolah (Ridwan, 2003 : 11).

Tidak setiap metode atau model pembelajaran dapat digunakan dalam setiap kompetensi dasar. Metode atau model pembelajaran yang digunakan guru hendaknya inovatif, menarik, tidak monoton serta disesuaikan dengan kompetensi dasar yang ingin dicapai. Sudjana (2005: 28), menyatakan upaya untuk membangkitkan atau Hasil belajar peserta didik yaitu menggunakan cara atau metode atau model pembelajaran dan media yang bervariasi, karena dengan metode atau model pembelajaran dan media yang bervariasi kebosanan dapat dihalangi.

Menurut Suciati (2005:91), langkahlangkah dalam model pembelajaran
Multilevel Group dimulai dengan berfikir, pembelajaran ini diawali dengan guru mengajukan pertanyaan atau isu terkait dengan pelajaran untuk dipikirkan oleh peserta didik. Guru memberi kesempatan kepada mereka memikirkan jawabannya. Selanjutnya berkelompok atau berpasangan, pada tahap ini guru meminta peserta didik berkelompok (group) atau berpasangan dengan teman sebangkunya. Beri kesempatan kepada masing-masing kelompok itu untuk berdiskusi. Diharapkan diskusi ini dapat memperdalam makna dari jawaban yang telah dipikirkan melalui intersubjektif dengan teman sebangkunya. Hasil diskusi intersubjektif di tiap-tiap kelompok pasangan hasilnya didiskusikan atau ditampilkan dengan kelompok pasangan seluruh kelas. Dalam kegiatan ini diharapkan terjadi tanya jawab yang mendorong pada pengontruksian pengetahuan secara integratif. Sebagai contoh, seorang guru baru saja menyelesaikan suatu sajian pendek atau para peserta didik telah selesai membaca suatu tugas. Selanjutnya guru meminta kepada para peserta didik untuk menyadari secara serius mengenai apa yang telah dijelaskan oleh guru atau apa yang telah dibaca. Guru memilih untuk membandingkan tanya jawab kelompok pasangan keseluruhan.

Menurut Frank Lyman (1985) dalam Suciati (2005: 80) pengertian model pembelajaran Multilevel Group adalah model pembelajaran peserta didik dapat menemukan pemikiran, saling bertukar pendapat, saling bekerja sama jika ada teman dalam satu kelompok yang mengalami kesulitan kemudian secara bertingkat.

Multilevel Group memberi peserta didik kesempatan untuk bekerja sendiri serta bekerja sama dengan orang lain. Keunggulan lain dari pembelajaran ini adalah optimalisasi partisipasi peserta 
Rahwini

didik. Dengan metode klasikal yang memungkinkan hanya satu peserta didik maju dan membagikan hasilnya untuk seluruh kelas, tapi pembelajaran ini memberi kesempatan sedikitnya delapan kali lebih banyak kepada peserta didik untuk dikenali dan menunjukkan partisipasi mereka kepada orang lain.

Langkah-langkah pembelajaran kooperatif Multilevel Group adalah sebagai berikut (Nasution, 2007: 57):

a. Langkah 1 - Berpikir : Guru mengajukan pertanyaan atau isu yang terkait dengan pelajaran dan peserta didik diberi waktu untuk memikirkan pertanyaan atau isu tersebut secara mandiri.

b. Langkah 2 - Berkelompok atau berpasangan (Group) : Guru meminta para peserta didik untuk berkelompok berpasangan dan mendiskusikan mengenai apa yang telah dipikirkan. Interaksi selama periode ini dapat menghasilkan jawaban bersama jika suatu pertanyaan telah diajukan atau penyampaian ide bersama telah diidentifikasi. Biasanya guru memberi waktu tidak lebih dari 4 atau 5 menit.

c. Langkah 3 - Berbagi bertingkat (Multilevel): Pada langkah akhir ini guru meminta kelompok pasanganpasangan tersebut untuk berbagi atau bekerjasama dengan kelas secara keseluruhan mengenai apa yang telah mereka bicarakan. Diawali dengan berkelompok dengan teman sebangkunya, dilanjutkan kelompok pasangan 2 atu 3 bergabung menjadi satu. Pada langkah ini akan menjadi efektif jika guru berkeliling kelas dari kelompok pasangan satu ke kelompok pasangan yang lain, sehingga seperempat atau separo dari kelompok pasangan tersebut memperoleh kesempatan untuk melapor.
Kelebihan dan kekurangan pada model pembelajaran Multilevel Group dalam proses pembelajaran, menurut Aisyah (2007:12) menyatakan bahwa. Kelebihan model pembelajaran kooperatif tipe Multilevel Group adalah:

a. Memungkinkan peserta didik untuk merumuskan dan mengajukan pertanyaan-pertanyaan mengenai materi yang diajarkan karena secara tidak langsung memperoleh contoh pertanyaan yang diajukan oleh guru, serta memperoleh kesempatan untuk materi yang diajarkan.

b. Peserta didik akan terlatih menerapkan konsep karena bertukar pendapat dan pemikiran dengan temannya untuk mendapatkan kesepakatan dalam memecahkan masalah.

c. Peserta didik lebih aktif dalam pembelajaran karena menyelesaikan tugasnya dalam kelompok.

d. Peserta didik memperoleh kesempatan untuk mempersentasikan hasil diskusinya dengan seluruh peserta didik sehingga ide yang ada menyebar.

e. Memungkinkan guru untuk lebih banyak memantau peserta didik dalam proses pembelajaran.

Adapun kelemahan model pembelajaran kooperatif tipe Multilevel Group adalah sangat sulit diterapkan di sekolah yang ratarata kemampuan peserta didiknya rendah dan waktu yang terbatas.

\section{Metode Penelitian}

Penelitian ini adalah penelitian tindakan kelas (PTK), yang dalam istilah bahasa Inggris disebut Classroom Action Research. Penelitian tindakan kelas adalah penelitian tindakan yang dilakukan di dalam kelas dengan tujuan memperbaiki atau meningkatkan mutu praktik pembelajaran (Suharsimi Arikunto dkk, 2009: 58). Penelitian tindakan kelas berfokus pada kelas atau pada proses belajar mengajar 
yang terjadi di kelas. PTK dapat diartikan sebagai upaya yang ditujukan untuk memperbaiki proses pembelajaran atau memecahkan masalah yang dihadapi dalam pembelajaran.

Penelitian ini dilaksanakan di Kelas VI Sekolah SDN Ketawang Karay I Kecamatan Ganding Kabupaten Sumenep Semester 1 Tahun pelajaran 2018/2019. Subjek yang diteliti adalah peserta didik Kelas VI SDN Ketawang Karay I Kecamatan Ganding Kabupaten Sumenep semester 1 tahun pelajaran 2018/2019, dengan jumlah 13 peserta didik, yang terdiri dari 4 laki-laki dan 9 perempuan.

Jenis data pada penelitian ini adalah data kuantitatif diwujudkan dalam nilai yang diperoleh peserta didik yang diambil dengan cara memberikan tes evaluasi pada saat sebelum dan sesudah diadakan tindakan penelitian. Data kuantitatif diperoleh dari hasil tes pada setiap siklus. Hasil tes ditulis dengan langkah - langkah sebagai berikut :

1) Merekap skor yang diperoleh Peserta didik.

2) Menghitung skor komulatif dari tugastugas Peserta didik.

3) Menghitung skor rata-rata.

4) Menghitung prosentase.

Untuk menghitung skor rata-rata Peserta didik menggunakan rumus:

Mean $=\frac{\sum \times}{\mathrm{n}}$

Keterangan :

Mean $=$ nilai rata - rata

$\Sigma X \quad=$ Jumlah seluruh Peserta didik

$\mathrm{n} \quad=$ Banyaknya Peserta didik

Untuk menghitung prosentase nilai ratarata Peserta didik menggunakan rumus:

$\mathrm{SP}=\frac{S K}{R} \times 100 \%$
Keterangan :

SP $=$ Skor Prosentase

SK $=$ Skor Komulatif

$\mathrm{R}=$ Responden

Hasil perhitungan prosentase nilai ratarata peserta didik dari tes ini kemudian dibandingkan antara pra siklus dengan siklus I, siklus I dengan siklus II. Hasil tes ini akan memberikan gambaran mengenai peningkatan hasil belajar peserta didik melalui model pembelajaran Multilevel Group dan pemberian tugas.

Sedangkan data kualitatif digunakan untuk menganalisis data nontes. Data kualitatif ini diperoleh dari data observasi dan pengamatan. Adapun langkah-langkah analisis data kualitatif adalah dengan menganalisis lembar observasi yang telah diisi dan mengklarifikasikannya dengan teman sejawat yang membantu dalam penelitian. Data pengamatan dilakukan pada saat pelaksanaan pembelajaran dari pra siklus sampai siklus 2 mata pelajaran Matematika materi KPK dan FPB melalui model pembelajaran Multilevel Group.

Menurut Supardi (Sugiyono, 2009:127) prinsip pengumpulan data dalam penelitian tindakan kelas tidak jauh berbeda dengan prinsip pengumpulan data pada jenis penelitian yang lain. Teknik pengumpulan data merupakan langkah yang paling utama dalam penelitian, karena tujuan utama dari penelitian adalah memperoleh data. Data penelitian ini bersumber dari peserta didik Kelas VI SDN Ketawang Karay I dengan menggunakan model pembelajaran Multilevel Group. Dalam penelitian ini, teknik pengumpulan data yang digunakan antara lain tes dan observasi.

1. Dokumen

Dokumentasi adalah mencari data mengenai hal-hal yang berupa catatan, transkip, buku, surat kabar, majalah, prasasti, notulen rapat, agenda dan sebagainya. Ada bermacam-macam dokumen yang dapat digunakan dalam 
Rahwini

penelitian. Dalam penelitan ini, instrumen yang penulis gunakan adalah hasil dokumentasi dari pelaksanaan pembelajaran di SDN Ketawang Karay I dengan menggunakan model pembelajaran Multilevel Group.

Teknik pengumpulan data dengan dokumentasi ialah pengambilan data yang diperoleh melalui dokumendokumen penelitian. Metode ini dilakukan untuk memperoleh daftar nama peserta didik yang termasuk dalam subjek penelitian, data-data yang berkaitan dengan sekolah, mulai dari struktur organisasi, daftar nama peserta didik yang menjadi subjek, pengambilan foto-foto dokumentasi selama proses pelaksanaan siklus dan daftar nilai peserta didik pada mata pelajaran Matematika.

2. Tes

Tes adalah serentetan pertanyaan atau latihan serta alat lain yang digunakan untuk mengukur keterampilan, pengetahuan intelegensi, kemampuan atau bakat yang dimiliki oleh individu atau kelompok. Tes yang digunakan dalam penelitian ini adalah tes tertulis. Peserta didik diberi tes tertulis pada setiap akhir siklus, untuk mengetahui keefektifan tindakan dengan mengacu pada indikator keberhasilan yang telah ditentukan.

Tes yang digunakan adalah ulangan dengan bentuk soal essay dengan jumlah soalnya 10 butir yang diberikan setiap akhir siklus. Test ini bertujuan untuk mengetahui hasil belajar peserta didik setelah dilakukan pembelajaran dengan menggunakan model pembelajaran Multilevel Group. Cara pengumpulan datanya yaitu, data hasil belajar diambil dari hasil evaluasi berupa tes yang diberikan peserta didik pada akhir siklus.

3. Observasi

Observasi sebagai teknik pengumpulan data mempunyai ciri yang spesifik karena tidak terbatas pada orang, tetapi juga pada objek-objek alam yang lain (Sugiyono, 2009: 145). Dalam penelitian ini, observasi atau pengamatan dilakukan untuk mengetahui aktifitas peserta didik selama proses pembelajaran. Observasi sangat penting dilakukan dengan sangat hati-hati agar data yang diperoleh benar-benar akurat. Dalam pelaksanaan observasi di kelas, observer yang mengamati aktifitas peserta didik dalam proses pembelajaran adalah rekan guru peneliti (teman sejawat).

\section{Hasil dan Pembahasan \\ Siklus I}

Dari analisis data prestasi yang dicapai peserta didik pada pembelajaran siklus I bahwa nilai yang dicapai peserta didik nilai terendah adalah 40 sedangkan nilai tertinggi adalah 100 dengan rata-rata kelas 71 . Dengan demikian dapat disimpulkan bahwa pembelajaran yang menitikberatkan pada model pembelajaran Multilevel Group sudah ada kemajuan. Akan tetapi belum dapat menuntaskan hasil belajar peserta didik. Oleh karena itu, direncanakan pembelajaran siklus II. 
Rekapitulasi Hasil Evaluasi Peserta didik

Berdasarkan Analisis Pembelajaran Pra Siklus

\begin{tabular}{|c|c|c|}
\hline No & Rentang Nilai & Banyak Peserta didik \\
\hline 1 & $0-19$ & 0 \\
\hline 2 & $20-39$ & 2 \\
\hline 3 & $40-69$ & 8 \\
\hline 4 & $70-89$ & 3 \\
\hline 5 & $90-100$ & 0 \\
\hline \multicolumn{2}{|c|}{ Jumlah Peserta didik } & 13 \\
\hline
\end{tabular}

Rekapitulasi Hasil Evaluasi Peserta didik Berdasarkan Analisis Pembelajaran Siklus I

\begin{tabular}{|c|c|c|}
\hline No & Rentang Nilai & Banyak Peserta didik \\
\hline 1 & $0-19$ & 0 \\
\hline 2 & $20-39$ & 0 \\
\hline 3 & $40-69$ & 5 \\
\hline 4 & $70-89$ & 6 \\
\hline 5 & $90-100$ & 2 \\
\hline \multicolumn{2}{|c|}{ Jumlah Peserta didik } & 13 \\
\hline
\end{tabular}

Dari hasil pengolahan data peserta didik pada pra siklus yaitu pada tabel pada mata pelajaran Matematika dengan materi KPK dan FPB dengan menggunakan model pembelajaran Multilevel Group kelas VI SDN Ketawang Karay I Kecamatan Ganding Kabupaten Sumenep menunjukkan bahwa dari 13 peserta didik yang mencapai tuntas belajar dengan nilai e" 70 hanya 3 peserta didik atau 23\%. Sedangkan 10 peserta didik lainnya atau $77 \%$ belum bisa mencapai ketuntasan belajar. Berdasarkan permasalahan tersebut maka untuk meningkatkan hasil belajar peserta didik terhadap Matematika tersebut, peneliti melakukan pembelajaran melalui pola Penelitian Tindakan Kelas (PTK) pada pembelajaran siklus I.

Setelah diadakan pembelajaran siklus I pada tabel dapat dilihat dan dinyatakan ada perubahan peningkatan hasil belajar peserta didik 13 peserta didik kelas VI semester 1 tahun pelajaran 2018/2019 di SDN Ketawang Karay I Kecamatan Ganding Kabupaten Sumenep yang mendapat nilai e" 70 semula hanya 3 peserta didik (23\%) meningkat menjadi 8 peserta didik (62\%).

Dengan peningkatan hasil belajar peserta didik tersebut karena peneliti dalam melaksanakan kegiatan pembelajaran siklus I masih kurang berhasil mencapai ketuntasan belajar, meskipun sudah menggunakan model pembelajaran Multilevel Group. Terbukti masih ada 5 peserta didik yang belum tuntas sehingga peneliti merancang pembelajaran siklus II. Berikut diagram yang menjelaskan peningkatan perolehan hasil belajar prasiklus dan hasil pembelajaran siklus I. 
Rahwini

Perolehan Nilai Prasiklus dan Siklus I

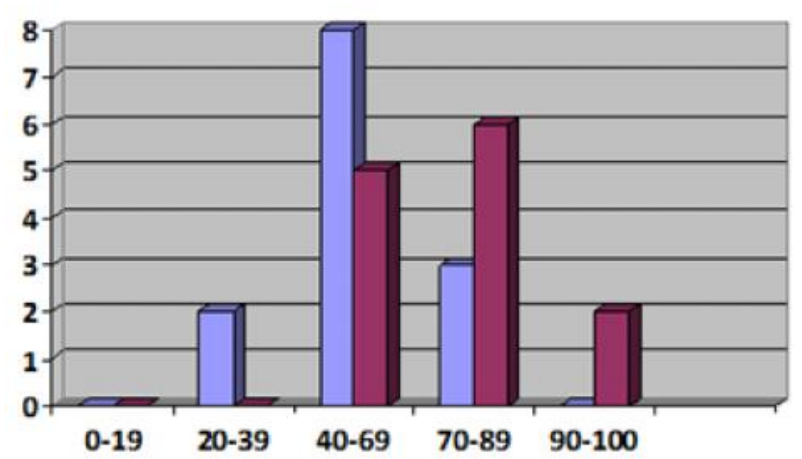

$\square$ Pra Siklus

๑ Siklus I

Berikut hasil pengamatan perilaku pengamat sebagai berikut: peserta didik yang telah diamati oleh

Hasil Pengamatan Aktivitas Peserta Didik Siklus 1

\begin{tabular}{|c|l|c|c|c|c|c|c|}
\hline \multirow{2}{*}{ No } & \multirow{2}{*}{$\begin{array}{c}\text { Aspek Yang } \\
\text { Diamati }\end{array}$} & $\begin{array}{c}\text { Jumlah } \\
\text { peserta } \\
\text { didik }\end{array}$ & $\begin{array}{c}\text { persen } \\
\text { tase }\end{array}$ & $\begin{array}{c}\text { Jumlah } \\
\text { peserta } \\
\text { didik }\end{array}$ & $\begin{array}{c}\text { persen } \\
\text { tase }\end{array}$ & $\begin{array}{c}\text { Jumlah } \\
\text { peserta } \\
\text { didik }\end{array}$ & $\begin{array}{c}\text { persen } \\
\text { tase }\end{array}$ \\
\hline 1 & Percaya diri & 3 & $23 \%$ & 4 & $31 \%$ & 6 & $46 \%$ \\
\hline 2 & Keaktifan & 6 & $46 \%$ & 3 & $23 \%$ & 4 & $31 \%$ \\
\hline 3 & Motivasi & 5 & $38 \%$ & 1 & $8 \%$ & 7 & $54 \%$ \\
\hline 4 & Kerjasama & 5 & $38 \%$ & 3 & $23 \%$ & 5 & $38 \%$ \\
\hline
\end{tabular}

Aktivitas peserta didik yang diamati dalam penelitian ini adalah aktivitas di dalam kelas. Adapun aspek yang diamati adalah rasa percaya diri, keaktifan, motivasi, dan kerjasama dalam melaksanakan tugas yang diberikan guru. Dari tabel diatas, didapat hasil sebagai berikut: 6 peserta didik kurang kurang percaya diri, 4 peserta didik cukup percaya diri dan 3 peserta didik percaya diri sudah baik. Dari aspek keaktifan, 4 peserta didik kurang, 3 peserta didik cukup dan 6 peserta didik sudah baik. Dari aspek motivasi, 7 peserta didik kurang, 1 peserta didik cukup dan 5 peserta didik sudah baik. Sedangkan dari aspek kerjasama, 5 peserta didik kurang, 3 peserta didik cukup, dan 5 peserta didik sudah baik. Dari hasil tersebut dapat digambarkan dengan diagram 4.2 di bawah ini:

\section{Hasil Pengamatan Aktivitas Peserta Didik Siklus I}
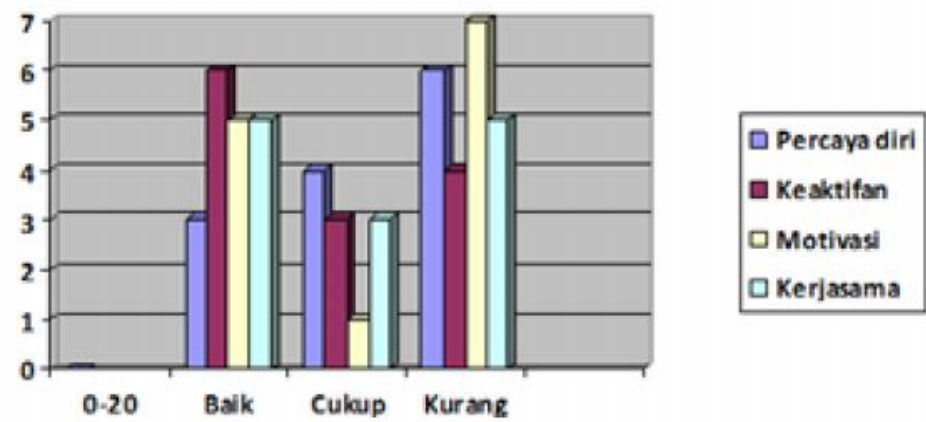
ISSN 2548-9119

\section{Siklus II}

Hasil temuan dari pengamatan selama pembelajaran yang dilaksanakan dengan menerapkan model pembelajaran Multilevel Group didapat hasil rata-rata kelas 84 dan ketuntasan klasikal 92\%, jika dibandingkan dengan pembelajaran siklus I yaitu dengan rata-rata kelas 71 dan ketuntasan klasikal $62 \%$. Maka dengan ini pada pembelajaran siklus II meningkat yaitu dari ketuntasan klasikal $62 \%$ menjadi $92 \%$.

Dari analisis data prestasi pada pembelajaran siklus II diketahui bahwa nilai yang dicapai peserta didik nilai terendah adalah 60 sedangkan nilai tertinggi adalah 100 dengan rata-rata kelas 84. Dengan demikian dapat disimpulkan bahwa pembelajaran yang menitik beratkan pada model pembelajaran Multilevel Group sudah mampu meningkatkan penguasaan materi yang ditunjukkan dengan peningkatan nilai hasil tes formatif yaitu dengan rata-rata kelas 84 dengan ketuntasan klasikal 92\%.

Namun demikian dalam proses pembelajaran siklus II masih ada kekurangannya, yaitu belum semua peserta didik dapat tuntas dalam pembelajaran, terbukti masih ada 1 peserta didik yang memperoleh nilai di bawah standar KKM yang ditentukan. Berikut peneliti sajikan data hasil belajar siklus II sebagaimana disajikan dalam tabel di bawah ini.

Rekapitulasi Hasil Evaluasi Peserta Didik

Berdasarkan Analisis Pembelajaran Siklus II

\begin{tabular}{|c|c|c|}
\hline No & Rentang Nilai & Banyak Peserta didik \\
\hline 1 & $0-19$ & 0 \\
\hline 2 & $20-39$ & 0 \\
\hline 3 & $40-69$ & 1 \\
\hline 4 & $70-89$ & 5 \\
\hline 5 & $90-100$ & 7 \\
\hline \multicolumn{2}{|c|}{ Jumlah Peserta didik } & 13 \\
\hline
\end{tabular}

Berdasarkan tabel dapat diketahui bahwa pada siklus II terjadi peningkatan hasil belajar yang signifikan yaitu rata-rata 84 dengan tingkat ketuntasan mencapai
92\%. Berikut diagram yang menjelaskan peningkatan perolehan hasil belajar prasiklus, siklus I, dan Siklus II.

\section{Perolehan Nilai Prasiklus, Siklus I, dan Siklus II}

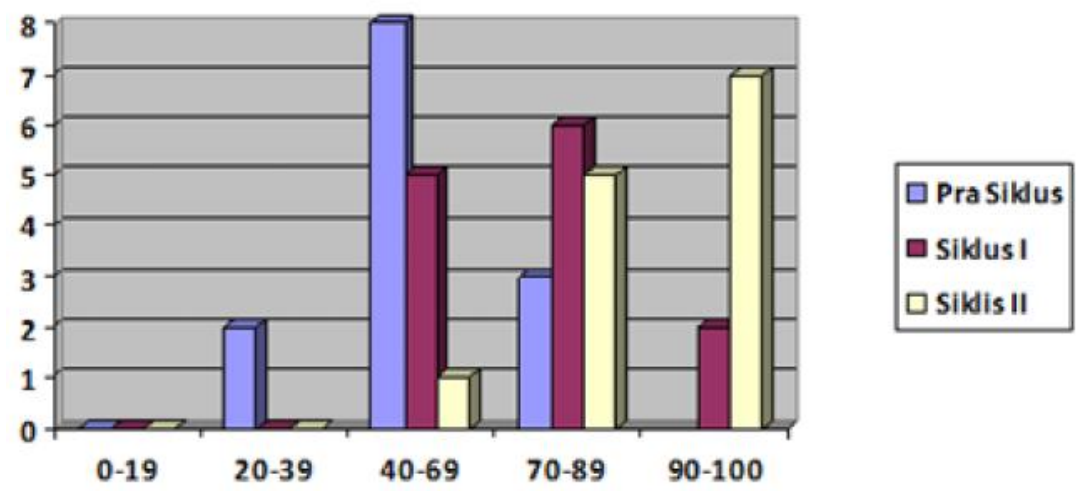


Rahwini

Selanjutnya Dari hasil pengamatan perilaku peserta didik yang telah diamati

oleh pengamat didapatkan hasil sebagai

berikut:

Hasil Pengamatan Aktivitas Peserta Didik Kegiatan Siklus II

\begin{tabular}{|c|l|c|c|c|c|c|c|}
\hline \multirow{2}{*}{ No } & \multirow{2}{*}{$\begin{array}{c}\text { Aspek Yang } \\
\text { Diamati }\end{array}$} & $\begin{array}{c}\text { Jumlah } \\
\text { peserta } \\
\text { didik }\end{array}$ & $\begin{array}{c}\text { persen } \\
\text { tase }\end{array}$ & $\begin{array}{c}\text { Jumlah } \\
\text { peserta } \\
\text { didik }\end{array}$ & $\begin{array}{c}\text { persen } \\
\text { tase }\end{array}$ & $\begin{array}{c}\text { Jumlah } \\
\text { peserta } \\
\text { didik }\end{array}$ & $\begin{array}{c}\text { persen } \\
\text { tase }\end{array}$ \\
\hline 1 & Percaya diri & 9 & $69 \%$ & 3 & $23 \%$ & 1 & $8 \%$ \\
\hline 2 & Keaktifan & 8 & $62 \%$ & 3 & $23 \%$ & 2 & $15 \%$ \\
\hline 3 & Motivasi & 8 & $62 \%$ & 3 & $23 \%$ & 2 & $15 \%$ \\
\hline 4 & Kerjasama & 9 & $69 \%$ & 1 & $8 \%$ & 3 & $23 \%$ \\
\hline
\end{tabular}

Aktivitas peserta didik yang diamati dalam penelitian ini adalah aktivitas di dalam kelas. Adapun aspek yang diamati adalah rasa percaya diri, keaktifan, motivasi, dan kerjasama dalam melaksanakan tugas yang diberikan guru. Dari tabel diatas, didapat hasil sebagai berikut: 1 peserta didik kurang kurang percaya diri, 3 peserta didik cukup percaya diri dan 9 peserta didik percaya diri sudah baik. Dari aspek keaktifan, 2 peserta didik kurang, 3 peserta didik cukup dan 8 peserta didik sudah baik. Dari aspek motivasi, 2 peserta didik kurang, 3 peserta didik cukup dan 8 peserta didik sudah baik. Sedangkan dari aspek kerjasama, 3 peserta didik kurang, 1 peserta didik cukup, dan 9 peserta didik sudah baik. Dari hasil tersebut dapat digambarkan dengan diagram 4 dibawah ini:

\section{Hasil Pengamatan Aktivitas Peserta Didik Siklus II}
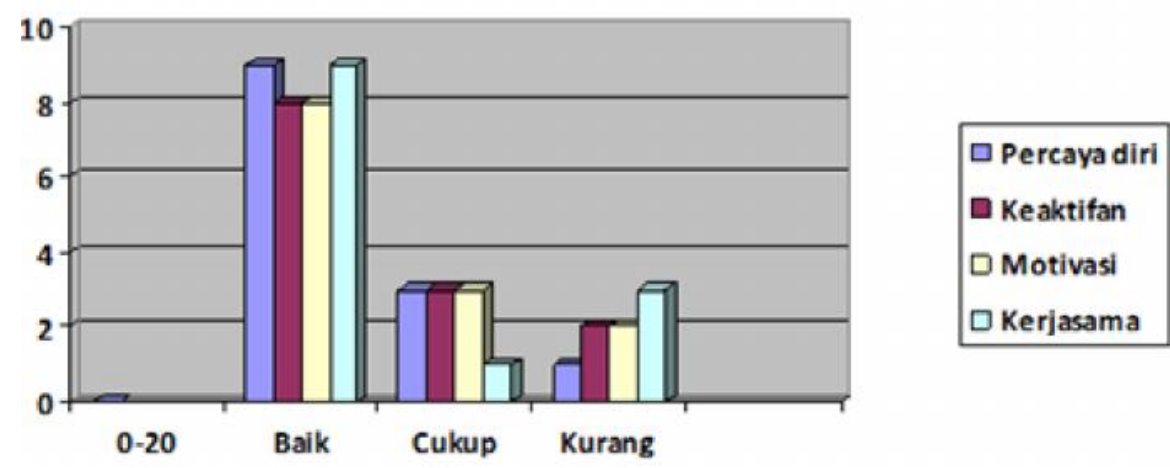

Adapun hal-hal singkat yang mendasari dalam proses pembelajaran yang terjadi pada pembelajaran siklus II yaitu peserta didik diberikan perlakuan yang berbeda dalam menerapkan model pembelajaran Multilevel Group pada pembelajaran di siklus I peneliti dalam menyampaikan materi pembelajaran menggunakan model pembelajaran Multilevel Group yang masih belum maksimal karena kesempatan peserta didik untuk presentasi masih rendah kemudian ditingkatkan lagi pada siklus II peneliti menitikberatkan pada model pembelajaran Multilevel Group.

Sebelum pembelajaran siklus I dilaksanakan, peserta didik memperoleh hasil rendah pada materi KPK dan FPB yaitu nilai rata-rata kelas 71 dan ketuntasan 
klasikal 62\%, dinyatakan belum mencapai indikator ketuntasan klasikal yang telah ditentukan yaitu e" $80 \%$. Kegagalan ini disebabkan kurangnya variasi atau perlakuan yang diberikan peneliti selama proses pembelajaran diprasiklus yaitu dalam pelaksanaanya hanya menggunakan metode ceramah dan tanya jawab, dapat dinyatakan bahwa usaha yang dilakukan guru dalam proses pembelajaran masih kurang sehingga usaha atau aktivitas belajar peserta didik menjadi berkurang yang mengakibatkan hasil belajar peserta didik tidak maksimal. Maka dari uraian permasalahan yang terjadi tersebut guru melaksanakan penelitian pembelajaran siklus I. Permasalahan yang mendasari diprasiklus akan diperbaiki dengan perlakuan di pembelajaran siklus I yaitu guru sebagai peneliti menerapkan model pembelajaran Multilevel Group.

Persentase ketuntasan ketuntasan klasikal pada siklus I adalah $62 \%$ dengan nilai rata-rata kelas dari 71 , dinyatakan belum mencapai indikator ketuntasan klasikal yang telah ditentukan yaitu e" $80 \%$. Guru sebagai peneliti dan dibantu teman sejawat sebagai observer melaksanakan refleksi dari hasil kegiatan pembelajaran siklus I dan memperoleh kesimpulan bahwa hasil dari siklus I perlu ditingkatkan lagi karena perlakuan atau usaha dalam proses pembelajaran di siklus I masih ada kekurangannya sehingga hasil yang diperoleh masih bisa ditingkatkan lagi, dengan perlakuan dan usaha dalam proses pembelajaran semakin tinggi maka hasil belajar peserta didik bisa semakin tinggi, sehingga memperoleh hasil yang maksimal, dapat disimpulkan bahwa peserta didik akan berhasil dalam belajar jika terdapat proses usaha yang maksimal, sehingga proses tersebut akan mempengaruhi perubahan perilaku peserta didik dalam segala hal yang dipikirkan dan dikerjakan.
Pembelajaran siklus II diperoleh hasil rata-rata kelas peserta didik 84 dan ketuntasan klasikal 92\%, dapat dikatakan sudah mencapai indikator ketuntasan klasikal yang telah ditentukan yaitu e" $80 \%$. Pembelajaran siklus II, jika dibandingkan dengan pembelajaran di siklus I hasil belajar peserta didik mengalami peningkatan yaitu dari rata-rata 71 menjadi 84, dengan ketuntasan klasikal dari 62\% menjadi 92\%. Membuktikan bahwa dengan proses usaha atau modifikasi perlakuan dalam belajar semakin meningkat dengan modifikasi perlakuan yang dilaksanakan oleh peneliti lewat model pembelajaran Multilevel Group, dengan cara ini peserta didik dalam memperoleh pengalaman belajar lebih baik dari sebelumnya.

Dari uraian di atas dapat dipahami bahwa penerapan model pembelajaran Multilevel Group dapat meningkatkan aktivitas dan hasil belajar siswa kelas VI SDN Ketawang Karay I dalam mata pelajaran Matematika materi KPK dan FPB sehingga perlu dikembangkan lebih lanjut.

\section{Kesimpulan}

Penggunaan model pembelajaran Multilevel Group dapat meningkatkan keaktifan peserta didik dalam pembelajaran Matematika materi KPK dan FPB di kelas VI SDN Ketawang Karay I Kecamatan Ganding Kabupaten Sumenep Semester 1 Tahun Pelajaran 2018/2019. Pada aspek percaya diri, pada siklus I dengan kategori baik, aspek percaya diri $23 \%$, aspek keaktifan $46 \%$, aspek motivasi belajar 38\%, dan aspek kerjasama 38\%. Pada siklus II dengan kategori baik, meningkat yaitu aspek percaya diri menjadi $69 \%$, aspek keaktifan menjadi $62 \%$, aspek motivasi belajar menjadi $62 \%$, dan aspek kerjasama menjadi $69 \%$.

Penggunaan model pembelajaran Multilevel Group dapat meningkatkan hasil belajar peserta didik dalam pembelajaran 
Rahwini

Matematika materi KPK dan FPB di kelas

ketuntasan klasikal 23\%, pada siklus I nilai VI SDN Ketawang Karay I Kecamatan rata- rata kelas menjadi 71 dengan Ganding Kabupaten Sumenep Semester 1 ketuntasan klasikal $62 \%$, dan pada siklus II Tahun Pelajaran 2018/2019. Pada tahap prasiklus nilai rata-rata kelas 55 dengan nilai rata- rata meningkat menjadi 84 dengan ketuntasan klasikal 92\%.

\section{DAFTAR PUSTAKA}

Arikunto, Suharsimi dkk. 2009. Penelitian Tindakan Kelas. Jakarta: PT Bumi Aksara.

Ariyadi Wijaya.2009. Pendidikan Matematika Realistik, Suatu Alternatf Pendekatan Pembelajaran Matematika. Yogyakarta: Graha IImu.

BSNP.2006. Panduan Kurikulum Tingkat Satuan Pendidikan. Jakarta

BSNP.2006. Buku Matematika untuk SD/MI Kelas VI. Jakarta: Pusbuknas.

Clara Ika Sari Budhayanti. 2008. Pemecahan Masalah Matematika. Jakarta: Depdiknas.

Dimyati \& Mudjiono.2002. Belajar dan Pembelajaran. Jakarta: PT. Rineka Cipta.

Fajariyah, Nur.2008. Cerdas Berhitung Matematika 6. Jakarta: Departemen Pendidikan Nasional.

Gatot Muhsetyo.2009. Pembelajaran Matematika SD, Modul Universitas Terbuka. Jakarta: Universitas Terbuka.

Hamalik, Oemar. 2007. Proses Belajar Mengajar, Jakarta: Bumi Aksara.

Heruman. 2007. Model Pendidikan Matematika. Bandung: Remaja Rosdakarya.

Ibrahim, dkk.1993. Materi Pokok Pengembangan Inovasi dan Kurikulum. Jakarta: Universitas Terbuka.

Kusumaatmaja, Nursid.2003. Pembelajaran Kooperatif. Depdikbud. Jakarta.

Marsigit.2003. Metodologi Pembelajaran Matematika. Makalah Pembinaan Guru Matematika. Yogyakarta: FMIPAUNY.

Muhibbin Syah. 2008. Psikologi Pendidikan dengan Pendekatan Baru.Bandung: Remaja Rosda karya.

Nana Sudjana. 2005. Dasar-Dasar Proses Belajar Mengajar. Bandung: Sinar Baru Algensindo Offset. 
ISSN 2548-9119

Nasution.2007. Berbagai Pendekatan Dalam Proses Belajar Dan Mengajar. Jakarta : Bumi Aksara.

Nyimas Aisyah.2007. Pengembangan Pembelajaran Matematika SD. Jakarta: Depdiknas.

Ridwan, Beny.2003.Cooperative Learning sebuah Metode Pembelajaran. Jakarta : Gramedia

Suciati. 2005. Belajar dan Pembelajaran. Jakarta: Universitas Terbuka.

Sugiyono. 2009. Metode Penelitian Pendidikan. Bandung: Alfabeta

Suharsimi Arikunto. 2010. Prosedur Penelitian, Suatu Pendekatan Praktik.

Zainal, Aqib.2004. Karya Tulis IImiah Bagi Pengembangan Profesi Guru. Bandung: Irama Widya.

Zaini, Hisyam.2005. Model-Model Pembelajaran: Jakarta : PT Aneka Cipta. Jakarta: Rineka Cipta. 